\title{
Penelitian
}

\section{Infestasi Cacing Parasitik pada Insang Ikan Mujair (Oreochromis mossambicus)}

\author{
(Infestation of Parasitic Worm at Mujair's Gills (Oreochromis mossambicus)) \\ Fitri Dinar Rahayu', Damiana Rita Ekastuti², Risa Tiuria ${ }^{{ }^{*}}$ \\ 'Bagian Parasitologi dan Entomologi, Departemen Ilmu Penyakit Hewan dan Kesehatan Masyarakat Veteriner, \\ Fakultas Kedokteran Hewan Institut Pertanian Bogor \\ 2Bagian Fisiologi, Departemen Anatomi, Fisiologi, dan Farmakologi, Fakultas Kedokteran Hewan, \\ Institut Pertanian Bogor, Jl. Agatis Kampus IPB Dramaga Bogor, 16680 Indonesia \\ *Penulis untuk korespondensi: rtiuria@yahoo.com \\ Diterima 22 Oktober 2012, Disetujui 8 Januari 2013
}

\begin{abstract}
ABSTRAK
Penelitian mengenai infestasi cacing parasitik pada insang ikan mujair (Oreochromis mossambicus) di kolam Kecamatan Dramaga dan kolam Kecamatan Ciomas-Bogor telah dilakukan. Penelitian dilakukan dengan metode deskriptif. Dari 13 sampel ikan mujair yang diperiksa, diperoleh 12 sampel ikan mujair terinfeksi cacing parasitik dan 1 sampel ikan mujair tidak terinfeksi cacing parasitik. Cacing parasitik yang berasal dari kelas Trematoda sub kelas Monogenea yaitu Dactylogyrus sp, Discocotyle sp, dan Gyrodactylus sp serta sub kelas Digenea ditemukan di kolam Kecamatan Dramaga. Cacing parasitik yang berasal dari sub kelas Monogenea yaitu Dactylogyrus sp, Tetraonchus sp dan Gyrodactylus sp ditemukan di kolam Kecamatan Ciomas. Jumlah seluruh cacing parasitik yang diisolasi dari kolam Kecamatan Dramaga berjumlah 50 ekor dengan nilai indeks prevalensi $85,7 \%$. Jumlah seluruh cacing parasitik yang diisolasi dari kolam Kecamatan Ciomas berjumlah 136 ekor dengan nilai indeks prevalensi sebesar $100 \%$. Berat badan ikan akan tergantung pada jenis cacing parasitik yang menginfeksinya dan sifat toleransi individual ikan.
\end{abstract}

Kata kunci: insang, Oreochromis mossambicus, Dactylogyrus sp, Gyrodactylus sp, prevalensi kecacingan.

\begin{abstract}
The research concerning infestation of parasitic worm at Mujair's gills (Oreochromis mossambicus) in the pool of Dramaga subdistrict and pool of Ciomas-Bogor subdistrict was done. The research method was carried out with the descriptive method. Of the 13 samples examined, we obtained 12 of mujair fish infected with parasitic worms and a mujair fish samples not infected with parasitic worms. In the pool of Dramaga subdistrict two sub class of parasitic worms were found class Trematoda sub class Monogenea such as Dactylogyrus sp, Discocotyle sp, Gyrodactilus sp and class Trematoda sub class Digenea. In the pool of Ciomas district sub class Monogenea of parasitic worms were found such as Dactylogyrus sp, Tetraonchus sp, and Gyrodactilus sp. The quantity of parasitic worm in the pool of Dramaga subdistrict is 50 worms with the prevalensi index is $85,7 \%$. The prevalensi in the pool of Ciomas district is more than pool of Dramaga subdistrict. The quantity of parasitic worm in the pool of Ciomas district is 136 worms with the value of the prevalensi index is $100 \%$. Fish weight will depend on the type of parasitic worm that infects and tolerant nature of individual fish.
\end{abstract}

Key words: gill, Oreochromis mossambicus, Dactylogyrus sp, Gyrodactylus sp, prevalence and worm intensity.

\section{PENDAHULUAN}

Potensi sumberdaya perikanan di Indonesia sangat berlimpah baik di perairan darat maupun di perairan laut. Sumberdaya perikanan terutama ikan dapat dimanfaatkan untuk kepentingan rakyat sebagai sumber protein hewani yang bernilai gizi tinggi. Masyarakat Indonesia mengenal ikan mu- 
jair sebagai bahan pangan yang paling murah (Sumantadinata, 1981). Ikan mujair termasuk ke dalam jenis ikan konsumsi air tawar dengan bentuk badan pipih berwarna abu-abu, coklat atau hitam. Ikan mujair pertama kali ditemukan di sebuah muara Kali Serang di Pantai Selatan oleh seorang kontak tani (penghubung) yang kemudian ditetapkan nama ilmiahnya Oreochromis mossambicus. Ikan mujair mempunyai toleransi yang besar terhadap kadar salinitas, temperatur air yang tinggi, perubahan lingkungan, kadar $\mathrm{pH}$, konsentrasi oksigen terlarut yang rendah, serta konsentrasi amonia yang tinggi dibandingkan dengan ikan air tawar lainnya. Ikan mujair mempunyai kecepatan pertumbuhan yang relatif lebih cepat untuk hidup di perairan seperti sungai, waduk, sawah, maupun rawa-rawa (Effendi, 2008).

Masalah utama yang sering dihadapi oleh para pembudidaya ikan diantaranya adalah penyakit pada ikan. Penyakit ikan sebagian besar disebabkan adanya kontaminasi yang berasal dari luar tubuh (eksternal) baik yang bersifat infeksius maupun non infeksius. Organ-organ yang sering terpapar oleh agen penyakit diantaranya adalah insang, saluran pencernaan, dan otot ikan. Salah satu penyebab terjadinya penyakit tersebut adalah parasit (Cheng, 1973). Ada berbagai jenis parasit yang telah diketahui di dunia kedokteran hewan seperti parasit jenis ektoparasit dan endoparasit. Salah satu jenis endoparasit yang sering dijumpai pada ikan adalah cacing. Cacing parasitik memiliki dampak besar bagi kesehatan dan kesejahteraan hewan maupun manusia. Adanya cacing parasitik di dalam tubuh ikan akan menyebabkan penurunan produksi dan bobot badan ikan, serta dapat menurunkan ketahanan tubuh ikan terhadap penyakit-penyakit lain (Levine, 1990).

Menurut FAO (2005), prevalensi penyebaran cacing parasitik di Indonesia dapat mencapai $\pm 30 \%$. Infeksi cacing parasitik di negara-negara berkembang termasuk Indonesia ini memiliki tingkat prevalensi penyebaran yang sangat tinggi. Tingkat penyebaran ini dipengaruhi oleh iklim dan cuaca. Iklim menentukan endemisitas suatu penyakit, sedangkan cuaca menentukan prevalensi penularan suatu penyakit parasitik sampai timbulnya epidemik. Selain itu umur, jenis kelamin, dan sistem ketahanan tubuh menentukan jumlah cacing parasitik yang menginfeksi induk semang (Tizard, 1987).

Program pengendalian penyakit cacing parasitik, akan efektif apabila dirancang berdasarkan informasi akurat tentang kejadian penyakit serta faktor-faktor resiko yang mempengaruhinya. Proses identifikasi cacing parasitik merupakan lang- kah awal yang harus diperhatikan dalam program pengendalian penyakit cacing parasitik (Sukarban, 1996). Identifikasi cacing parasitik ini berguna untuk mengetahui famili, genus, dan spesies cacing tersebut. Informasi tentang kejadian cacing parasitik pada insang ikan mujair masih sangat kurang sehingga perlu dilakukan banyak studi yang mengemukakan kecacingan pada ikan.

Tujuan penelitian ini untuk mengetahui keragaman jenis dan identifikasi jenis cacing parasitik pada insang ikan mujair yang diharapkan dapat memberikan informasi tentang jenis cacing parasitik yang terdapat pada insang ikan mujair (Oreochromis mossambicus).

\section{BAHAN DAN METODE}

Pengambilan Sampel Ikan Mujair (Oreochromis mossambicus)

Sampel ikan mujair diambil secara acak pada dua tempat yaitu 7 ekor di kolam Kecamatan Dramaga dan 6 ekor di kolam Kecamatan Ciomas, Bogor. Sampel ikan dimasukkan ke dalam kantong plastik yang telah diberi air dan oksigen secukupnya. Selanjutnya sebelum dilakukan nekropsi pada ikan, sampel dimasukkan ke dalam akuarium di Laboratorium Helmintologi selama 1-2 hari .

\section{Pengambilan Insang dan Isolasi Cacing}

Sampel ikan terlebih dahulu ditimbang berat badannya dan selanjutnya dibuat sayatan di bagian ventral ikan yang dimulai dari daerah kloaka hingga ke anterior yaitu operculum ikan untuk memaparkan insang. Organ insang dimasukkan ke dalam cawan petri yang telah diisi $\mathrm{NaCl}$ fisiologis $0,85 \%$ dan diletakkan dalam lemari pendingin bersuhu $4^{\circ} \mathrm{C}$ beberapa jam agar supaya cacing parasitik dapat berelaksasi sehingga dapat melepaskan kaitnya dari insang ikan. Cacing parasitik yang telah diisolasi dari organ insang kemudian dimasukkan ke dalam botol plastik berisi alkohol 70\% dan gliserin. Tahap selanjutnya adalah dilakukan pewarnaan terhadap cacing parasitik (Soulsby, 1982).

\section{Metode Pewarnaan}

Metode pewarnaan menggunakan pewarnaan permanen Semichon's Acetocarmine. Spesimen cacing direndam dalam larutan Acetocarmine selama \pm 15-20 menit hingga warna terserap (spesimen menjadi warna merah cerah). Spesimen cacing di- 
bilas dengan menggunakan alkohol 70\% dan direndam dalam larutan asam alkohol (99 bagian etanol 70\% dan 1 bagian dalam $\mathrm{HCl}$ ) selama 5-7 menit. Setelah itu direndam selama 5 menit dengan alkohol secara bertahap (70\%, 85\%, 95\%, dan absolut) untuk tujuan dehidrasi. Kemudian dilanjutkan dengan clearing, yaitu membuat spesimen menjadi lebih jernih dengan menggunakan xylol dan dimounting dengan Entellan pada gelas objek (Yamaguti, 1958).

\section{Identifikasi Cacing Parasitik}

Identifikasi cacing parasitik yang telah terwarnai diamati di bawah mikroskop. Cacing parasitik diukur panjang dan lebar tubuhnya untuk selanjutnya diidentifikasi berdasarkan morfologi dengan mengacu pada Yamaguti (1958), Soulsby (1982), serta Noble \& Noble (1989).

\section{Analisis Data}

Untuk menghitung prevalensi (pendugaan proporsi) dari sampel dapat dilakukan dengan menggunakan rumus perhitungan statistik sebagai berikut:

$$
\text { Prevalensi }=\frac{\begin{array}{c}
\text { Jumlah ikan yang terinfeksi } \\
\text { cacing parasitik }
\end{array}}{\text { Jumlah ikan yang diperiksa }} \times 100 \%
$$

\section{HASIL}

Cacing Parasitik dari Insang Ikan Mujair (Oreochromis mossambicus)

Hasil yang ditemukan dari gambaran infestasi cacing parasitik pada insang ikan mujair (Oreochromis mossambicus) menunjukkan hampir seluruh sampel ikan mujair yang diambil dari kolam Kecamatan Dramaga dan kolam Kecamatan Ciomas positif terinfeksi cacing parasitik. Dari tujuh sampel ikan mujair yang diperiksa dari kolam Kecamatan Dramaga didapatkan enam ekor ikan mujair terinfeksi cacing parasitik dan satu ekor ikan mujair tidak ditemukan adanya cacing parasitik. Sedangkan dari kolam Kecamatan Ciomas, keseluruhan sampel ikan mujair terinfeksi cacing parasitik.

Tingkat Prevalensi Cacing Parasitik pada Insang Ikan Mujair (Oreochromis mossambicus)

Tingkat prevalensi cacing parasitik yang ditemukan pada insang ikan mujair (Oreochromis mossambicus) dapat dilihat pada Tabel 1.

Identifikasi Jenis Cacing Parasitik pada Insang Ikan Mujair (Oreochromis mossambicus)

Hasil identifikasi cacing parasitik yang ditemukan pada insang ikan mujair (Oreochromis mossambicus) dapat dikelompokkan ke dalam kelas Trematoda dari philum Platyhelminthes. Cacing parasitik yang ditemukan pada insang ikan mujair di kolam Kecamatan Dramaga terdiri dari 2 sub kelas yaitu sub kelas Monogenea dan sub kelas Digenea. Cacing parasitik kelas Trematoda sub kelas Monogenea terdiri dari cacing Dactylogyrus sp, Discocotyle sp, dan Gyrodactylus sp. Akan tetapi cacing parasitik kelas Trematoda sub kelas Digenea hanya di identifikasi sampai sub kelas, hal ini dikarenakan kurang begitu jelasnya organ tubuh dari cacing parasitik. Cacing parasitik yang ditemukan pada insang ikan mujair di kolam Kecamatan Ciomas terdiri dari 1 sub kelas, yaitu sub kelas Monogenea yang terdiri dari cacing Dactylogyrus sp, Tetraonchus sp dan Gyrodactylus sp.

Jumlah Cacing Parasitik pada Ikan Mujair (Oreochromis mossambicus)

Jumlah cacing parasitik yang ditemukan di kolam Kecamatan Darmaga dan di kolam Kecamatan Ciomas dapat dilihat pada Tabel 2 dan 3.

Tabel 1. Tingkat Prevalensi Cacing Parasitik pada Insang Ikan Mujair di Kolam Kecamatan Dramaga dan di Kolam Kecamatan Ciomas

\begin{tabular}{lccc}
\hline \multicolumn{1}{c}{ Lokasi Pengambilan Sampel } & $\begin{array}{c}\text { Jumlah ikan yang } \\
\text { diperiksa (ekor) }\end{array}$ & $\begin{array}{c}\text { Jumlah ikan yang } \\
\text { terinfeksi (ekor) }\end{array}$ & $\begin{array}{c}\text { Prevalensi } \\
(\%)\end{array}$ \\
\hline Kolam Kecamatan Darmaga & 7 & 6 & 85,7 \\
Kolam Kecamatan Ciomas & 6 & 6 & 100 \\
\hline
\end{tabular}


1. Cacing Parasitik dari Sub Kelas Monogenea
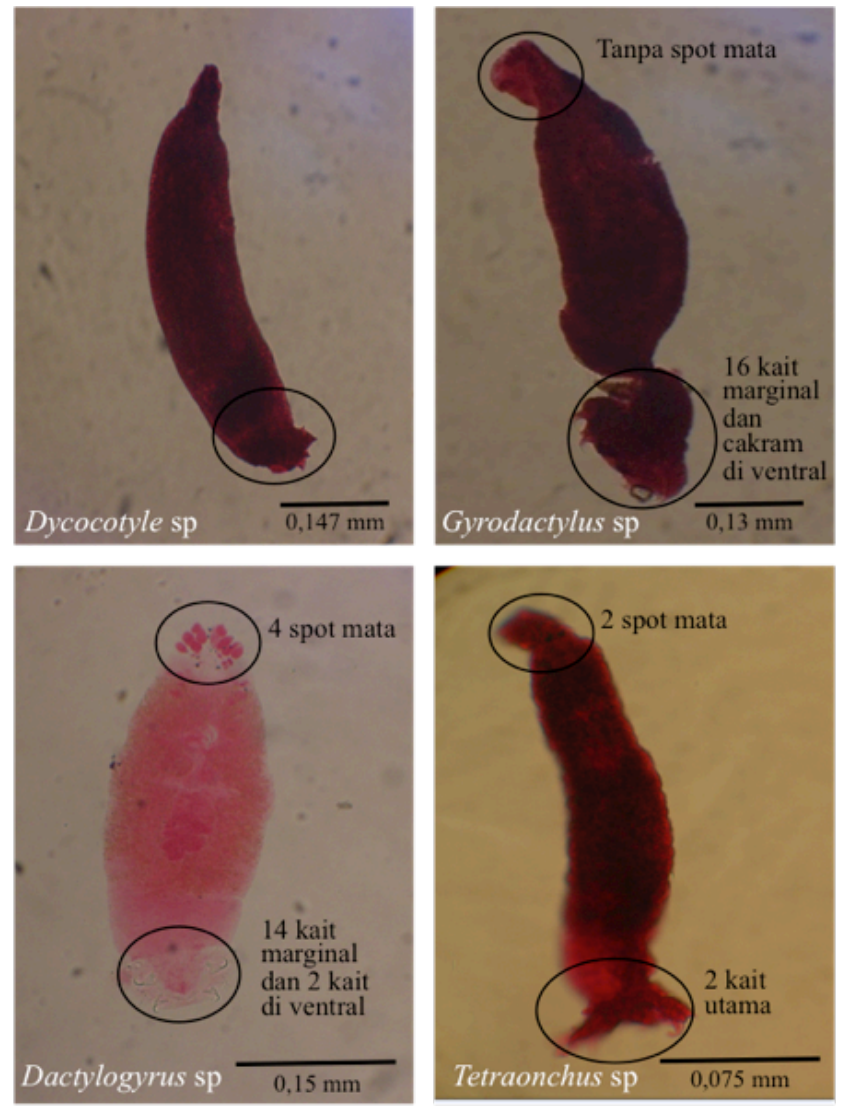

2. Cacing Parasitik dari Sub Kelas Digenea

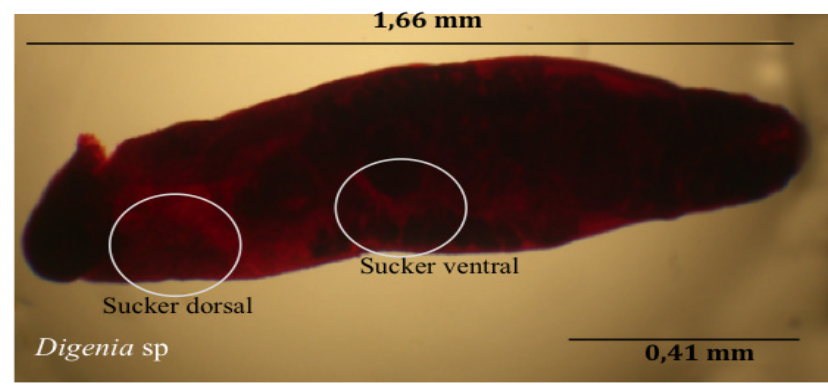

Gambar 1 Cacing Parasitik Pada Insang Ikan Mujair (Oreochromis mossambicus)

Pada Tabel 4 dan 5 dapat dilihat jenis-jenis cacing parasitik yang ditemukan pada masing-masing interval berat badan ikan mujair yang diperiksa dari kolam Kecamatan Dramaga dan Kecamatan Ciomas, Bogor.

\section{PEMBAHASAN}

Keanekaragaman cacing parasitik dalam suatu kolam dapat dipengaruhi oleh faktor salinitas dan suhu yang sangat berpengaruh terhadap pertumbuhan cacing parasitik. Kadar salinitas yang tinggi dapat menghambat pertumbuhan cacing parasitik khususnya cacing Trematoda sub kelas Monogenea. Hal ini disebabkan karena cacing Monogenea tidak dapat memberikan toleransi adanya garam dalam tubuhnya. Selain itu, cacing Monogenea juga sangat rentan terhadap perubahan suhu. Ada beberapa jenis cacing Monogenea yang hanya bisa berkembang pada suhu yang tinggi atau pada suhu yang rendah.

Menurut Cheng (1973), penyakit parasit pada ikan dapat timbul dari interaksi antara jasad penyebab penyakit parasit dengan lingkungannya. Hal ini dapat disebabkan karena adanya proses pembusukan di dasar kolam baik terhadap kotoran hasil metabolisme maupun sisa makanan serta zatzat buangan yang masuk ke dalam kolam sehingga dapat memperburuk kondisi perairan. Hubungan antara inang dengan parasit merupakan hal yang kompleks karena adanya faktor yang berpengaruh

Tabel 2 Jumlah Cacing Parasitik Per Ekor Ikan Mujair yang Ditemukan di Kolam Kecamatan Dramaga.

\begin{tabular}{lcc}
\hline BB $(\mathrm{g})$ & $\begin{array}{c}\text { Sampel Ikan Mujair } \\
\text { yang Diperiksa (ekor) }\end{array}$ & $\begin{array}{c}\text { Jumlah Cacing } \\
\text { Parasitik (ekor) }\end{array}$ \\
\hline $90-100$ & 1 & 13 \\
$100-110$ & 1 & 4 \\
$110-120$ & 2 & 19 \\
$120-130$ & 2 & 14 \\
\hline
\end{tabular}

Tabel 3 Jumlah Cacing Parasitik Per Ekor Ikan Mujair yang Ditemukan di Kolam Kecamatan Ciomas.

\begin{tabular}{lcc}
\hline BB $(\mathrm{g})$ & $\begin{array}{c}\text { Sampel Ikan Mujair } \\
\text { yang Diperiksa (ekor) }\end{array}$ & $\begin{array}{c}\text { Jumlah Cacing } \\
\text { Parasitik (ekor) }\end{array}$ \\
\hline $130-140$ & 1 & 16 \\
$140-150$ & 1 & 23 \\
$150-160$ & 1 & 25 \\
$160-170$ & 2 & 29 \\
$170-180$ & 1 & 43 \\
\hline
\end{tabular}

seperti kualitas air yang buruk, kadar amoniak yang tinggi, serta populasi yang padat sehingga dapat memicu terjadinya perkembangan parasit. Penyebaran parasit yang patogen terhadap inang dapat ditentukan oleh umur, ukuran tubuh inang, daya tahan inang, musim dan lokasi geografisnya. 
12 | Rahayu et al.

Tabel 4 Jenis-Jenis Cacing Parasitik yang Ditemukan di Kolam Kecamatan Darmaga

\begin{tabular}{lccccc}
\hline \multirow{2}{*}{ BB $(\mathrm{g})$} & \multicolumn{5}{c}{ Jenis Cacing Parasitik } \\
\cline { 2 - 6 } & Dactylogyrus sp & Gyrodactilus sp & Discocotyle sp & Tetraonchus sp & Digenea \\
\hline $90-100$ & 7 & 2 & 4 & 0 & 0 \\
$100-110$ & 4 & 0 & 0 & 0 & 0 \\
$110-120$ & 18 & 0 & 0 & 0 & 0 \\
$120-130$ & 11 & 2 & 1 & 0 & 0 \\
\hline
\end{tabular}

Tabel 5 Jenis-Jenis Cacing Parasitik yang Ditemukan di Kolam Kecamatan Ciomas

\begin{tabular}{lccccc}
\hline \multirow{2}{*}{ BB $(\mathrm{g})$} & \multicolumn{5}{c}{ Jenis Cacing Parasitik } \\
\cline { 2 - 6 } & Dactylogyrus sp & Gyrodactilus sp & Discocotyle sp & Tetraonchus sp & Digenea \\
\hline $130-140$ & 16 & 0 & 0 & 0 & 0 \\
$140-150$ & 23 & 0 & 0 & 0 & 0 \\
$150-160$ & 2 & 18 & 0 & 5 & 0 \\
$160-170$ & 25 & 2 & 0 & 2 & 0 \\
$170-180$ & 43 & 0 & 0 & 0 & 0 \\
\hline
\end{tabular}

Cacing parasitik yang termasuk ke dalam kelas Trematoda sub kelas Monogenea dan sub kelas Digenea, merupakan jenis cacing parasitik yang sering menyerang ikan-ikan air tawar pada semua fase pertumbuhan mulai dari fase benih sampai dengan fase dewasa. Sebenarnya infeksi parasit ini tidak menyebabkan kematian seperti penyakit yang disebabkan oleh bakteri atau virus, namun infeksi parasit ini dapat menyebabkan luka pada tubuh yang dapat memicu terjadinya infeksi sekunder oleh bakteri ataupun virus. Infeksi sekunder inilah yang dapat menyebabkan kematian pada ikan. Pintu masuk penyakit pada ikan bisa melalui oral, inhalasi, serta kulit atau luka dan sebagian besar cacing parasitik masuk melalui insang ikan. Penyakit yang disebabkan oleh cacing parasitik yang menyerang insang sangat sulit untuk dideteksi secara dini. Salah satu cara yang dianggap cukup efektif untuk mengetahui adanya serangan parasit pada insang adalah dengan mengamati pola tingkah laku ikan. Ciri ikan yang terserang parasit diantaranya tutup insang akan mengembang sehingga sulit untuk ditutup dengan sempurna dan lembaran-lembaran insang akan terlihat lebih pucat apabila lokasi infeksinya meluas. Jika pada insang terlihat adanya bintik putih, kemungkinan besar disebabkan oleh adanya cacing parasitik yang menempel pada insang (Dogiel et al., 1961).

Tingkat prevalensi kecacingan menunjukkan besarnya persentase ikan mujair yang terinfeksi oleh cacing parasitik. Dari hasil analisis data yang diperoleh, tingkat prevalensi cacing parasitik dari kolam Kecamatan Dramaga sebesar $85,7 \%$, berdasarkan kategori yang dikembangkan oleh Williams \& Williams (1996), nilai prevalensi yang diperoleh dari analisis data termasuk ke dalam kategori cukup parah "usually" (89-70\%). Tingkat prevalensi cacing parasitik dari kolam Kecamatan Ciomas sebesar $100 \%$, berdasarkan kategori yang dikembangkan oleh Williams \& Williams (1996), nilai prevalensi ini termasuk ke dalam kategori sangat parah "always" (100-99\%). Dari data tingkat prevalensi yang diperoleh, kolam Kecamatan Dramaga dan kolam Kecamatan Ciomas memiliki tingkat prevalensi cacing parasitik yang sangat tinggi. Menurut Noble \& Noble (1989), tingginya prevalensi kecacingan dapat ditentukan oleh beberapa faktor diantaranya yaitu faktor ekstrinsik dan faktor intrinsik. Faktor ekstrinsik dapat dipengaruhi oleh habitat ikan itu sendiri seperti kualitas air, sumber air kolam, sanitasi kolam yang buruk, pakan ikan yang kurang, serta populasi ikan yang terlalu padat. Faktor intrinsik seperti kekebalan individu ikan, jenis kelamin, umur ikan, serta ukuran tubuh ikan.

Pada Tabel 2, interval berat badan 90-100 gram menunjukkan jumlah cacing parasitik yang paling tinggi dibanding dengan interval berat badan yang lain. Hal ini disebabkan karena salah satu cacing parasitik yang menginfeksi ikan mujair pada interval berat badan 90-100 gram adalah Discocotyle sp (Ta- 
bel 4). Discocotyle sp merupakan cacing parasitik yang bersifat patogen yang mampu menyebabkan kematian pada ikan, sehingga menyebabkan terjadinya penurunan berat badan. Terjadinya penurunan berat badan dikarenakan infestasi cacing parasitik Discocotyle sp yang menyerap darah ikan sehingga menyebabkan ikan cenderung lesu, anoreksia, anemia, gambaran hematokrit darah rendah, serta terlihat pucat di insang, hati dan ginjal. Selain itu, Discocotyle sp juga mampu menyebabkan kerusakan yang memicu terjadinya infeksi sekunder oleh bakteri sehingga ikan mengalami emasiasio (kekurusan) (Cheng, 1973).

Pada Tabel 3, interval berat badan 170-180 gram menunjukan jumlah cacing parasitik yang paling tinggi dibanding dengan interval berat badan yang lain. Hal ini disebabkan karena semua cacing parasitik yang menginfeksi ikan mujair pada interval berat badan 170-180 gram adalah Dactylogyrus $s p$ (Tabel 5). Dactylogyrus sp merupakan cacing parasitik yang tidak bersifat patogen, sehingga tidak mempengaruhi terjadinya penurunan berat badan akibat adanya infestasi cacing parasitik tersebut walaupun jumlahnya tinggi. Ikan yang terinfeksi Dactylogyrus sp akan memperlihatkan sekresi mukosa yang berlebihan serta ikan terlihat sesak nafas. Gejala ikan yang terinfeksi Dactylogyrus sp dapat ditangani dengan menjaga kualitas air agar tetap bersih. Hal ini disebabkan karena kualitas air yang bersih mampu mempercepat penyembuhan luka akibat infeksi Dactylogyrus sp serta dapat mencegah terjadinya infeksi ulang.

Jumlah cacing parasitik mengalami kenaikan meskipun fluktuatif seiring dengan bertambahnya berat badan ikan. Noble \& Noble (1989) mengatakan, bahwa semakin besar tubuh ikan maka ukuran insang pun akan semakin besar sehingga memungkinkan semakin banyaknya cacing parasitik yang menempel. Selain itu, umur ikan yang tua dapat menjadi lebih toleran untuk mengadaptasikan cacing parasitik dalam jumlah yang besar.

Tingginya jumlah cacing parasitik dapat disebabkan karena adanya faktor-faktor yang berpengaruh diantaranya kepadatan populasi ikan yang tinggi sehingga memungkinkan terjadinya kontak langsung dengan ikan yang terinfeksi parasit, adanya pintu masuk parasit melalui luka terbuka, kualitas air yang buruk, adanya perubahan suhu, masuknya jenis ikan yang baru bisa mengakibatkan masuknya parasit baru, predator yang bisa sebagai inang penular, serta sistem budidaya dengan menggunakan kolam tanah yang merupakan media bagi sebagian siklus hidup parasit.

Pada Tabel 4, Dactylogyrus sp memiliki tingkat infeksi yang sangat tinggi, kemudian diikuti oleh Discocotyle sp, Gyrodactylus sp, dan Digenea. Pada setiap interval berat berat badan ikan yang terinfeksi, secara umum genus Dactylogyrus sp selalu dominan bila dibandingkan dengan genus lainnya. Hal ini disebabkan karena Dactylogyrus sp memiliki penyebaran yang luas pada jenis ikan air tawar. Penyebaran Dactylogyrus sp ini terihat dari siklus hidupnya yang bersifat ovivar. Dactylogyrus sp dewasa akan menghasilkan telur yang banyak ke dasar air, kemudian berkembang menjadi larva dan bergerak bebas mencari inang definitif untuk perkembangannya. Selain itu, suhu lingkungan yang tinggi akan mengakibatkan perkembangbiakan Dactylogyrus sp semakin cepat. Cacing parasitik Tetraonchus sp tidak ditemukan pada kolam di Kecamatan Dramaga. Hal ini mungkin dikarenakan habitat kolam Kecamatan Dramaga kurang cocok untuk perkembangan Tetraonchus sp. Cacing parasitik Tetraonchus sp mampu berkembang pada suhu di atas $10^{\circ} \mathrm{C}$ dengan kadar salinitas yang rendah.

Pada Tabel 5, Dactylogyrus sp memiliki tingkat infeksi yang sangat tinggi, kemudian diikuti oleh Gyrodactylus sp dan Tetraonchus sp. Setiap interval berat badan ikan yang terinfeksi, secara umum genus Dactylogyrus sp di kolam Kecamatan Ciomas juga selalu dominan bila dibandingkan dengan genus lainnya. Di kolam Kecamatan Ciomas cacing parasitik Discocotyle sp dan Digenea tidak ditemukan. Hal ini mungkin dikarenakan habitat kolam Kecamatan Ciomas kurang cocok untuk perkembangan Discocotyle sp, dan Digenea. Cacing parasitik Discocotyle sp mampu hidup pada suhu antara $13-18^{\circ} \mathrm{C}$ dengan kadar salinitas yang rendah. Cacing parasitik Digenea memiliki siklus hidup yang kompleks dimana Digenea membutuhkan inang antara dalam proses perkembangannya.

Menurut Sumantadinata (1981), pengendalian penyakit parasitik yang efektif masih sulit dilakukan. Hal ini dikarenakan habitat air seperti sawah, rawa atau daerah yang basah merupakan daerah yang sangat rentan terserang penyakit cacing parasitik terhadap satwa akuatik khususnya ikan. Adapun cara pencegahan yang dapat dilakukan antaralain dengan pencegahan secara preventif maupun kuratif. Pencegahaan preventif dapat dilakukan dengan menjaga salinitas kolam dan kualitas air tetap bersih, pemberian pakan yang cukup, serta kepadatan populasi yang optimal. Pencegahan kuratif yang efektif dapat dilakukan dengan memberikan garam ke kolam baik dengan cara ditabur maupun dilarutkan. Hal ini dikarenakan cacing parasitik monogenea tidak dapat memberikan toleransi adanya garam didalam tubuhnya. 
Dari penelitian ini dapat disimpulkan bahwa cacing parasitik dari kelas Trematoda sub kelas Monogenea yaitu Dactylogyrus sp, Discocotyle sp, Gyrodactylus $s p$ dan dari kelas Trematoda sub kelas Digenea teridentifikasi dari kolam Kecamatan Darmaga dengan tingkat prevalensi sebesar $85,7 \%$. Cacing parasitik yang diidentifikasi dari kolam Kecamatan Ciomas berasal dari sub kelas Monogenea yaitu Dactylogyrus sp, Tetraonchus sp dan Gyrodactylus $s p$ dengan tingkat prevalensi sebesar $100 \%$. Berat badan ikan akan tergantung pada jenis cacing parasitik yang menginfeksinya dan sifat toleransi individual ikan. Sebagai saran perlu dilakukan penelitian upaya penanganan yang lebih baik untuk mengurangi terjadinya infeksi oleh parasit khususnya air, karena air merupakan salah satu faktor yang dapat meningkatkan prevalensi kecacingan.

"Penulis menyatakan tidak ada konflik kepentingan dengan pihak-pihak yang terkait dalam penelitian ini".

\section{DAFTAR PUSTAKA}

Cheng T. 1973. General Parasitology. New York: Academic Press.

Dogiel VA, GK Petrushevski dan YI Polyanski. 1961. Parasitology of Fishes. London: Oliver and Byod Ltd.

Effendi. 2008. Dinamika Hidup Ikan Mujair. http:// www.trobos.com/show article. Pada Tanggal 26 Maret 2010.
[FAO]. Food and Agriculture Organization. Corporate Document repository. 2005. Liver Fluke Infections. http://www.fao.org/DOCREP/004/ T0584E/T0584E03. htm. Pada Tanggal 18 Maret 2010.

Levine ND. 1990. Buku Pelajaran Parasitologi Veteriner. Prof. Dr. Gatut Ashadi, Penerjemah. Yogyakarta: Gajah Mada University Press. Terjemahan dari: Textbook of Veterinary Parasitology.

Noble ER, Noble GA. 1989. Parasitology: The Biology of Animal Parasites. $5^{\text {th }}$ Ed. Wardiarto, penerjemah: Soeripto, editor. Yogyakarta: Gajah Mada University Press.

Soulsby EJL. 1982. Helmints, Arthropods and Protozoa of Domesticated Animals. $7^{\text {th }}$ Ed. London. Baillire Tindall.

Sumantadinata K. 1981. Pengembangan Ikan-Ikan Peliharaan di Indonesia. Sastra Hudaya. p117.

Sukarban S. 1996. Farmakologi dan Terapi. Edisi-4. University Press. Jakarta.

Tizard I. 1987. Pengantar Imonologi Veteriner. Airlangga University Press. Surabaya. p497.

Williams EH Jr. and LB Williams. 1996. Parasities of Offshore Big Game Fishes of Puerto Rico and the Western Atlantic. Puerto Rico: Departement of Natural and Environmental Resources and University of Puerto Rico.

Yamaguti S. 1958. Systema Helminthum. Volume 1: Protozoan and Metazoan Infections. $2^{\text {nd }} E d$. Canada. 